\title{
Soil methane oxidation in both dry and wet temperate eucalypt forests shows a near-identical relationship with soil air-filled porosity
}

\author{
Benedikt J. Fest ${ }^{1}$, Nina Hinko-Najera ${ }^{2}$, Tim Wardlaw ${ }^{3}$, David W. T. Griffith ${ }^{4}$, Stephen J. Livesley ${ }^{1}$, and \\ Stefan K. Arndt ${ }^{1}$ \\ ${ }^{1}$ School of Ecosystem and Forest Sciences, The University of Melbourne, Richmond, 3121 Victoria, Australia \\ ${ }^{2}$ School of Ecosystem and Forest Sciences, The University of Melbourne, Creswick, 3363 Victoria, Australia \\ ${ }^{3}$ Forest Management Services Branch, Forestry Tasmania, Hobart, 7000 Tasmania, Australia \\ ${ }^{4}$ School of Chemistry, University of Wollongong, Wollongong, 2522 New South Wales, Australia \\ Correspondence to: Benedikt J. Fest (bfest@unimelb.edu.au)
}

Received: 5 May 2016 - Published in Biogeosciences Discuss.: 28 June 2016

Revised: 16 November 2016 - Accepted: 17 November 2016 - Published: 27 January 2017

\begin{abstract}
Well-drained, aerated soils are important sinks for atmospheric methane $\left(\mathrm{CH}_{4}\right)$ via the process of $\mathrm{CH}_{4}$ oxidation by methane-oxidising bacteria (MOB). This terrestrial $\mathrm{CH}_{4}$ sink may contribute towards climate change mitigation, but the impact of changing soil moisture and temperature regimes on $\mathrm{CH}_{4}$ uptake is not well understood in all ecosystems. Soils in temperate forest ecosystems are the greatest terrestrial $\mathrm{CH}_{4}$ sink globally. Under predicted climate change scenarios, temperate eucalypt forests in southeastern Australia are predicted to experience rapid and extreme changes in rainfall patterns, temperatures and wild fires. To investigate the influence of environmental drivers on seasonal and inter-annual variation of soil-atmosphere $\mathrm{CH}_{4}$ exchange, we measured soil-atmosphere $\mathrm{CH}_{4}$ exchange at high-temporal resolution $(<2 \mathrm{~h})$ in a dry temperate eucalypt forest in Victoria (Wombat State Forest, precipitation $870 \mathrm{~mm} \mathrm{yr}^{-1}$ ) and in a wet temperature eucalypt forest in Tasmania (Warra Long-Term Ecological Research site, $1700 \mathrm{~mm} \mathrm{yr}^{-1}$ ). Both forest soil systems were continuous $\mathrm{CH}_{4}$ sinks of $-1.79 \mathrm{~kg} \mathrm{CH}_{4} \mathrm{ha}^{-1} \mathrm{yr}^{-1}$ in Victoria and $-3.83 \mathrm{~kg} \mathrm{CH}_{4} \mathrm{ha}^{-1} \mathrm{yr}^{-1}$ in Tasmania. Soil $\mathrm{CH}_{4}$ uptake showed substantial temporal variation and was strongly controlled by soil moisture at both forest sites. Soil $\mathrm{CH}_{4}$ uptake increased when soil moisture decreased and this relationship explained up to $90 \%$ of the temporal variability. Furthermore, the relationship between soil moisture and soil $\mathrm{CH}_{4}$ flux was near-identical at both forest sites when soil moisture was expressed as soil air-filled porosity (AFP). Soil temperature only had a minor influence on soil $\mathrm{CH}_{4}$ uptake. Soil ni-
\end{abstract}

trogen concentrations were generally low and fluctuations in nitrogen availability did not influence soil $\mathrm{CH}_{4}$ uptake at either forest site. Our data suggest that soil MOB activity in the two forests was similar and that differences in soil $\mathrm{CH}_{4} \mathrm{ex}-$ change between the two forests were related to differences in soil moisture and thereby soil gas diffusivity. The differences between forest sites and the variation in soil $\mathrm{CH}_{4}$ exchange over time could be explained by soil AFP as an indicator of soil moisture status.

\section{Introduction}

Methane $\left(\mathrm{CH}_{4}\right)$ has a relatively low atmospheric concentration of approximately $1.8 \mathrm{ppm}$ and is, after carbon dioxide $\left(\mathrm{CO}_{2}\right.$, approx. $\left.402 \mathrm{ppm}\right)$, the second most abundant greenhouse gas in the atmosphere (IPCC, 2013). Although its atmospheric concentration is 2 orders of magnitude lower than that of $\mathrm{CO}_{2}, \mathrm{CH}_{4}$ accounts for approximately $18 \%$ of the currently observed global temperature increase (IPCC, 2013). In addition, $\mathrm{CH}_{4}$ contributes to $32 \%$ of the current radiative forcing created by the major greenhouse gases as it has a 25 times greater global warming potential compared to $\mathrm{CO}_{2}$ (IPCC, 2013).

Forest soils are the most important land-based sink for $\mathrm{CH}_{4}$ via the activity of methane-oxidising bacteria (MOB) in well-drained, aerobic soils. Soils in temperate forest ecosystems play an important role in global $\mathrm{CH}_{4}$ exchange between the land mass and the atmosphere and they constitute around 
30-50\% of the soil-based $\mathrm{CH}_{4}$ sink worldwide (Ojima et al., 1993; Dutaur and Verchot, 2007).

Major environmental factors controlling and influencing $\mathrm{CH}_{4}$ uptake rates by forest soils are soil diffusivity, soil structure, soil moisture, soil temperature and soil nitrogen status (Ball et al., 1997; Smith et al., 2003; von Fischer and Hedin, 2007; Butterbach-Bahl et al., 2002; Del Grosso et al., 2000).

The main factor regulating the $\mathrm{CH}_{4}$ uptake capacity of soils is the diffusion rate of $\mathrm{CH}_{4}$ through the soil and hence the substrate availability of $\mathrm{CH}_{4}$ to the MOB across the soil profile. $\mathrm{CH}_{4}$ uptake rates have been shown to decrease with increasing soil moisture as a result of decreasing soil gas diffusion rates across different ecosystems (Castro et al., 1995; Khalil and Baggs, 2005; Ball et al., 1997). Therefore, $\mathrm{CH}_{4}$ uptake is thought to be most rapid in coarse-textured forest soils with a well-developed structure and an organic surface layer that does not inhibit gas diffusion (Boeckx et al., 1997; Del Grosso et al., 2000; Smith et al., 2000). Soil bulk density can also correlate with soil $\mathrm{CH}_{4}$ uptake across different ecosystems (Smith et al., 2003, 2000), which is not unexpected since soil air-filled porosity, which is directly linked to soil diffusivity, is a function of soil bulk density and volumetric water content.

Soil $\mathrm{CH}_{4}$ uptake at atmospheric levels generally shows limited temperature dependency and reported $Q_{10}$ values are generally low with an average around 1.4 (Crill, 1991; Born et al., 1990; Smith et al., 2000). Another factor that influences the $\mathrm{CH}_{4}$ uptake capacity of soils is soil $\mathrm{N}$ status, especially the availability of ammonium $\left(\mathrm{NH}_{4}^{+}\right)$(ButterbachBahl et al., 1998; Sitaula et al., 1995). Increasing soil N availability through organic and inorganic fertiliser additions and through biological $\mathrm{N}$ fixation can decrease $\mathrm{CH}_{4}$ uptake rates (Niklaus et al., 2006; Dick et al., 2006).

Temperate eucalypt (broadleaved evergreen) forests in south-eastern Australia cover around 26 million hectares (Montreal Process Implementation Group for Australia and National Forest Inventory Steering Committee, 2013) and provide a large range of ecosystem services. However, despite a growing interest in soil $\mathrm{CH}_{4}$ uptake in the last decade there have been very few studies investigating $\mathrm{CH}_{4}$ oxidation in soils of natural Australian forest and woodland ecosystems, with only a relatively small number of published studies on $\mathrm{CH}_{4}$ uptake in temperate forest systems (Livesley et al., 2009; Meyer et al., 1997; Fest, 2013; Fest et al., 2009, 2015a, b), tropical forest systems (Kiese et al., 2003) and savanna ecosystems (Livesley et al., 2011). Moreover, there is currently no model that accurately predicts the size of the terrestrial $\mathrm{CH}_{4}$ sink in Australia or determines how the strength of this sink will change over time. Data describing $\mathrm{CH}_{4}$ emission and oxidation from Australian soils is still patchy and often lacking for important landscapes such as tropical savannas, the semi-arid and arid zones and woody ecosystems (Dalal et al., 2008).

Compared to most European and North American temperate forest systems, forest soils in the Australian temperate region are generally highly weathered and very low in nutrients and atmospheric nitrogen deposition is very low. Furthermore most of the temperate forest area in Australia does not experience periods of snow cover or below zero soil temperatures. It is therefore questionable as to whether information gathered on spatial and temporal variability of soil $\mathrm{CH}_{4}$ exchange in Northern Hemisphere temperate forest soils are transferable to those in Australia. Furthermore, it is not clear if processes that explain soil $\mathrm{CH}_{4}$ uptake in deciduous forest systems or coniferous forest systems worldwide can be directly transferred to the eucalypt or acacia forest systems that dominate the forests and woodlands of Australia. Most estimates of soil $\mathrm{CH}_{4}$ exchange in Australian forest systems were based on infrequent (weekly-monthly) or campaignbased measurements (of 1-2 weeks), which may not fully reflect the temporal dynamics and range of environmental conditions.

This study investigates soil-atmosphere $\mathrm{CH}_{4}$ exchange using automated chamber systems measuring at a hightemporal resolution over 1-2 years in two temperate Eucalyptus obliqua-dominated forest sites with contrasting annual precipitation. The main objectives of this study were to assess the magnitude and temporal variation in $\mathrm{CH}_{4}$ exchange between the soil and atmosphere in temperate evergreen eucalypt forest systems and to investigate the primary biophysical processes that control the seasonality in soil $\mathrm{CH}_{4}$ flux.

\section{Material and methods}

\subsection{Site description}

The Tasmanian site is in the Warra Long-Term Ecological Research (LTER) site approximately $60 \mathrm{~km}$ west-southwest of Hobart, Tasmania, Australia (AU-WRR: $43^{\circ} 5^{\prime} 36.78^{\prime \prime} \mathrm{S}$, $\left.146^{\circ} 38^{\prime} 42.65^{\prime \prime} \mathrm{E}\right)$. The site is dominated by Eucalyptus obliqua (L'Her.) with an overstorey height of around $53 \mathrm{~m}$ and a basal area of $54 \mathrm{~m}^{2} \mathrm{ha}^{-1}$. The understorey is mainly comprised of Acacia melanoxylon (R. Br.), Nothofagus cunninghamii (Hook.) Oerst. and Dicksonia antarctica (Labill.). The climate of AU-WRR is classified as temperate cool wet (Dunlop and Brown, 2008) with cold and wet winters and warm and wet summers. The average rainfall is approximately $1700 \mathrm{~mm} \mathrm{yr}^{-1}$ (Fig. 1a) with mean monthly maximum temperatures of $19.3^{\circ} \mathrm{C}$ in January (summer) and mean minimum temperatures of $2.5^{\circ} \mathrm{C}$ in July (winter). The soils at Warra are derived from Permian siltstone with a surface texture of silty loam to silty clay loam and are classified as Kurosolic Redoxic Hydrosol (McIntosh, 2012). The average bulk density in the top $5 \mathrm{~cm}$ of mineral soil is $0.67 \mathrm{~g} \mathrm{~cm}^{-3}$ and soil porosity is $0.74 \mathrm{~cm}^{3} \mathrm{~cm}^{-3}$.

The Victorian forest site is in the Wombat State Forest, approximately $120 \mathrm{~km}$ west of Melbourne, Australia (AUWOM: $37^{\circ} 25^{\prime} 20.83^{\prime \prime} \mathrm{S}, 144^{\circ} 5^{\prime} 38.63^{\prime \prime} \mathrm{E}$ ). AU-WOM is dominated by Eucalyptus obliqua (L'Her.), Eucalyptus rubida (H. 

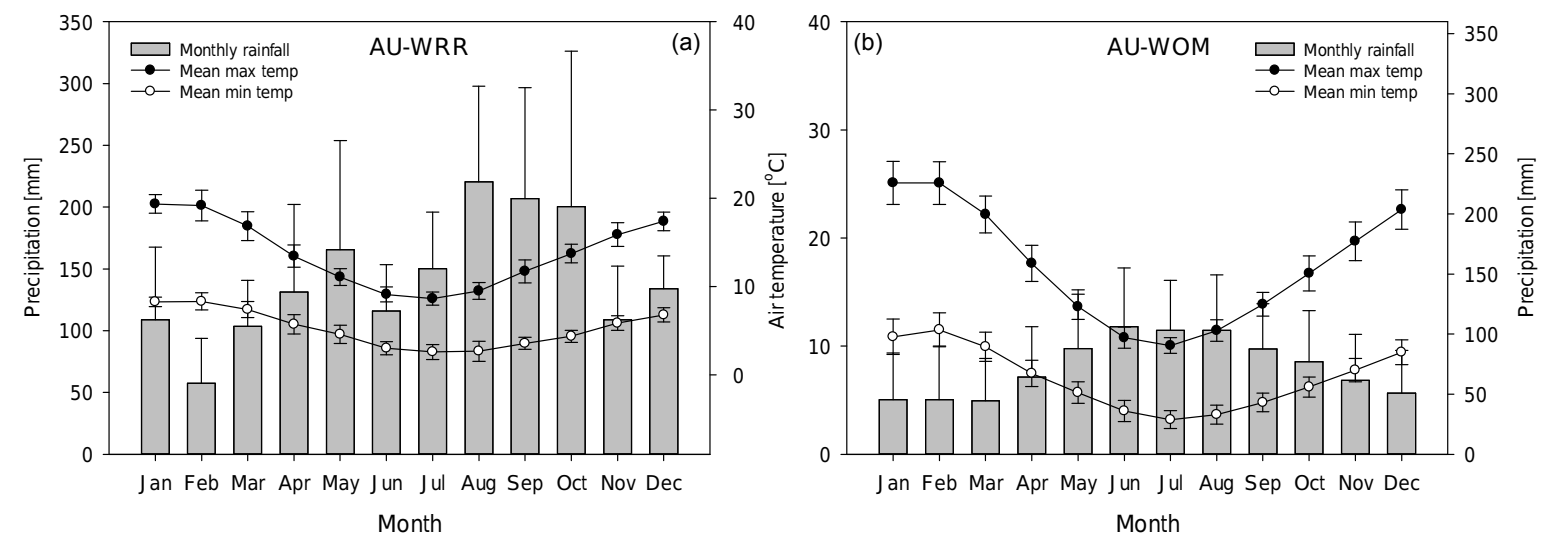

Figure 1. Climate at the investigated sites of (a) Warra Long-Term Ecological Research in Tasmania (AU-WRR) and (b) Wombat State Forest in Victoria (AU-WOM). Black circles represent monthly mean maximum air temperatures. White circles represent monthly mean minimum air temperatures. Grey bars represent monthly precipitation. Error bars represent \pm 1 SD. Data source: Bureau of Meteorology Australia, http://www.bom.gov.au (station numbers 097024 for AU-WRR and 088020 for AU-WOM).

Deane \& Maiden) and Eucalyptus radiata (Sieber ex DC.) trees of approximately $20-25 \mathrm{~m}$ in height and $37 \mathrm{~m}^{2} \mathrm{ha}^{-1}$ of stem basal area. The climate is classified as Mediterranean to cool temperate, with warm and dry summers and wet and cool winters. The average rainfall is approximately $870 \mathrm{~mm} \mathrm{yr}^{-1}$ (Fig. 1b) with mean monthly maximum temperatures of $25.6^{\circ} \mathrm{C}$ in January (summer) and mean minimum temperatures of $3.4^{\circ} \mathrm{C}$ in July (winter). The soils of AU-WOM are derived from weathered sandstone and shale, with a surface texture of sandy clay loam, classified as an acidic-mottled, dystrophic, yellow Dermosol (Robinson et al., 2003). The average bulk density in the top $5 \mathrm{~cm}$ of mineral soil is $0.90 \mathrm{~g} \mathrm{~cm}^{-3}$ and soil porosity is $0.65 \mathrm{~cm}^{3} \mathrm{~cm}^{-3}$.

\subsubsection{Experimental design AU-WRR}

The temporal variation in soil-atmosphere exchange of $\mathrm{CH}_{4}$ was monitored continuously from 10 October 2010 to 15 January 2012 using a fully automated gas chromatograph (GC) measurement system attached to 10 pneumatic open-andclose chambers as described in Livesley et al. (2009). This system was supported by a remote area power system consisting of a $5 \mathrm{~kW}$ diesel generator and $12 \mathrm{~V}$ battery bank. The 10 chambers were randomly distributed over an area of approximately $25 \times 25 \mathrm{~m}$. Chambers were attached to a square steel-frame base $($ e.g. $50 \times 50 \mathrm{~cm})$ which was inserted $5 \mathrm{~cm}$ into the soil and a plexiglass headspace of $15 \mathrm{~cm}$ depth (e.g. $37.5 \mathrm{~L}$ chamber volume). Chambers were attached to the frame using clamps and closed cell foam. For each chamber, six flux rate measurements were made during a $24 \mathrm{~h}$ period, one every $4 \mathrm{~h}$. Further details of the automated trace gas measurement system, chamber design and gas chromatograph can be found in Butterbach-Bahl et al. (1997), Papen and Butterbach-Bahl (1999) and Livesley et al. (2009). Soil temperature (12-Bit Temp Smart Sensor, Onset Computer Cooperation, USA) and moisture (EC-5 Soil Moisture Smart Sen- sor, Onset Computer Cooperation, USA) was logged at 0 $10 \mathrm{~cm}$ on a half-hourly basis (Hobo U30, Hobo Data Logger, Onset Computer Cooperation, USA) in the middle of the site. Chamber pneumatic lids opened automatically when rainfall, measured by a tipping bucket rain gauge, exceeded $1 \mathrm{~mm}$ in $5 \mathrm{~min}$ to avoid a potential reduction in soil moisture inside the chambers caused by the rainfall exclusion during the relatively long time of chamber closure $(2 \mathrm{~h})$.

\subsubsection{Experimental design AU-WOM}

Temporal variation in soil-atmosphere exchange of $\mathrm{CH}_{4}$ was monitored continuously from 1 May 2010 to 30 April 2012 using a fully automated Fourier transform infrared (FTIR) spectrometer measurement system attached to six pneumatic open-and-close chambers (Griffith et al., 2012). This system was supported by a remote area power system consisting of a $4.5 \mathrm{~kW}$ diesel generator and $24 \mathrm{~V}$ battery bank. The automatic chambers used followed the same design as that described at the AU-WRR site. The opening and closing of the lids via pneumatic pistons was controlled with the measuring software on site (Spectronous Software, Ecotech PTY Ltd). Six chambers were distributed randomly over an area of around $25 \times 25 \mathrm{~m}$ and were measured in sequence with each chamber initially having a measuring period of $15 \mathrm{~min}$ (1 May-21 October 2010) that was later extended to $20 \mathrm{~min}$ to increase detection precision for other simultaneously measured trace gases (22 October 2010-30 April 2012). Lids were open for both the first and the last 2 min of every $15 / 20$ min measuring interval per chamber to flush the sample lines with ambient air, resulting in a chamber incubation period of 11/16 min. One $\mathrm{CH}_{4}$ flux measurement per chamber was achieved every $1.5 / 2 \mathrm{~h}$. The chambers were not fitted with a fan, but there was forced ventilation during the incubation period of each chamber through the use of an external pump which circulated the air in a closed loop through the 
head-space of the chamber (closed dynamic set-up), attached airlines $(0.3 \mathrm{~L}$ tubing volume) and the measuring cell $(3.5 \mathrm{~L}$ cell volume) of a FTIR spectrometer set-up (Spectronus, Ecotech Pty. Ltd., Australia). The spectrometer (Bruker IRcube with globar source and thermoelectrically cooled mercury cadmium telluride detector) measured concentrations of $\mathrm{CH}_{4}, \mathrm{CO}_{2}, \mathrm{~N}_{2} \mathrm{O}$, carbon monoxide and water vapour in the air stream (Meyer et al., 2001; Griffith et al., 2012; Hammer et al., 2013). Measurements of the $\mathrm{CH}_{4}$ concentration were made every minute during the $15 / 20$ min chamber period. Further information about measuring principle, instrument set-up, maintenance and calibration can be found in Griffith et al. (2012). Soil temperature (thermocouple probe) and moisture (impedance probes, ML2x - Theta Probe Soil Moisture Sensor, Delta-T Devices Ltd., UK) was recorded continuously at $0-5 \mathrm{~cm}$ within each chamber. In addition, soil temperature (Averaging Soil Thermocouple Probe, TCAV, Campbell Scientific Australia) and soil moisture (Water Content Reflectometer, CS616, Campbell Scientific Australia) were recorded on a half-hourly basis at $0-10 \mathrm{~cm}$ by an on-site eddy covariance system. Given the relatively short closure period of 11/16 min for each chamber during a $4 \mathrm{~h}$ period, we decided that automated chamber opening in response to rainfall events was not necessary.

\subsection{Flux calculation}

$\mathrm{CH}_{4}$ flux rates were calculated for both automated measuring systems from the rate of increase/decrease of gas concentration in the chamber head space with time according to

$F_{\mu \mathrm{L}}=(V / A) \times\left(\mathrm{d} C_{\mathrm{CH}_{4}} / \mathrm{d} t\right)$,

where $V$ is the volume (L) of the chamber head space plus sample lines and the FTIR sample cell, $A$ is the soil surface area covered by the chamber $\left(\mathrm{m}^{2}\right)$ and $t$ is time. The term $\mathrm{d} C_{\mathrm{CH}_{4}} / \mathrm{d} t\left(\mu \mathrm{LL}^{-1} \mathrm{~h}^{-1}\right)$ was calculated from the initial linear $\mathrm{CH}_{4}$ concentration change after chamber closure. In cases where the fitted linear regression model had an $R^{2}<0.9$, this flux measurement was excluded from further analysis. The determined flux rate $\left(F_{\mu \mathrm{L}}\right)$ was subsequently converted to $\mu \mathrm{mol} \mathrm{CH}_{4} \mathrm{~m}^{-2} \mathrm{~h}^{-1}\left(F_{\mu \mathrm{mol}}\right)$ by accounting for temperature, pressure and volume using Eq. (2) based on the ideal gas law:

$F_{\mu \mathrm{mol}}=\left(F_{\mu \mathrm{L}} \times P\right) /(R \times T)$,

where $P$ is the atmospheric pressure in $\mathrm{kPa}$ at site according to altitude or direct measurement (Eddy tower), $R$ is 8.3144 (the ideal gas constant in $\mathrm{L} \mathrm{kPa}^{-1} \mathrm{~K}^{-1}$ ) and $T$ is the air temperature in kelvin $\left(273.15+{ }^{\circ} \mathrm{C}\right)$. Fluxes in $\mu \mathrm{mol} \mathrm{CH} \mathrm{C}_{4} \mathrm{~m}^{-2} \mathrm{~h}^{-1}$ were then converted to $\mu \mathrm{g} \mathrm{CH}_{4}$ $\mathrm{C} \mathrm{m}^{-2} \mathrm{~h}^{-1}$ based on the molecular atomic mass.

\subsection{Additional measurements}

From within each site, composite soil samples (three $0-5 \mathrm{~cm}$ samples) were collected, sieved $(2 \mathrm{~mm})$ and sub-sampled for
$1 \mathrm{M} \mathrm{KCl}$ extraction $(1: 4$, soil: $\mathrm{KCl})$ and gravimetric water content $\left(\mathrm{GWC}_{S}\right)$ determination $\left(105^{\circ} \mathrm{C}\right.$ for $\left.48 \mathrm{~h}\right)$ during additional seasonal measurement campaigns spread across the measurement time frame $(n=13$ in AU-WOM, $n=$ 10 in AU-WRR. $\mathrm{KCl}$ extracts were filtered (Whatman 42) and frozen prior to analysis for nitrate $\left(\mathrm{NO}_{3}^{-}\right)$and ammonium $\left(\mathrm{NH}_{4}^{+}\right)$concentration using an autoanalyser (SFA, Technicon $^{\mathrm{TM}}$ ).

During initial site installation (and over the course of the measurement time frame), approximately 30 volumetric soil cores $(0-5 \mathrm{~cm}, \varnothing 72 \mathrm{~mm})$ were sampled at each site to determine soil volumetric water content (VWC) and soil bulk density (BD). The data were used to establish site dependent calibration curves between the on-site installed soil moisture sensors (HOBO Micro Station Data Logger H21 and EC-5 Soil Moisture Smart Sensor, Onset Computer Corporation, USA), hand-held impedance probes (ML2 $\times$ Theta probe and HH2 Moisture Meter, Delta-T Devices Ltd., UK) and VWC (Kaleita et al., 2005). The bulk density and volumetric water content data and their relationship to the on-site installed soil moisture sensor readings and hand-held impedance probes readings were further used to calculate soil porosity, air-filled porosity and percentage water-filled pore space (\%WFPS) for each plot and measuring event according to Loveday and Commonwealth Bureau of Soils (1973) as follows:

soil porosity $=1-($ soil bulk density $/$ particle density $)$,

where a value of 2.65 was used for particle density $\left(\mathrm{g} \mathrm{cm}^{-3}\right)$ of rock, sand grains and other soil mineral particles;

air - filled porosity $=$
soil porosity - volumetric water content;

$\% \mathrm{WFPS}=$

(volumetric water content $\times 100$ ) /soil porosity.

At the end of the study, a composite soil sample from five soil cores was collected at $0-5 \mathrm{~cm}$ at each site, air dried, sieved $(2 \mathrm{~mm})$ and analysed for soil particle size analysis through dispersion, suspension, settling and sequential hydrometer readings (Ashworth et al., 2001). A sub-sample of each airdried soil was analysed for $\mathrm{pH}(1: 5$, soil : water $)$ and for total $\mathrm{C}$ and $\mathrm{N}$ content using an elemental analyser $\left(\mathrm{LECO}^{\circledR}\right)$.

\subsection{Data presentation and statistical analyses}

Flux and environmental sensor data presented (if not specifically related to individual chambers) in the figures here after are averages for respective chamber cycles where at least two-thirds of the chamber flux measurements had passed the above mentioned flux quality control $(1.5 / 2 \mathrm{~h}$ cycle for the FTIR system and a $4 \mathrm{~h}$ cycle average for the GC system) at each site $\pm 1 \mathrm{SE}$ (where error bars are present). We also calculated the coefficient of variance per chamber cycle $\left(\mathrm{CV} \%_{\text {cycle }}\right)$ by dividing the standard deviation of each chamber cycle by its respective mean and multiplying the result 
Table 1. Parameters and coefficients of determination (Adj. $R^{2}$ is adjusted R-squared) of linear regression models explaining seasonal variability in mean chamber cycle methane flux $\left(F_{\mathrm{CH}_{4}}\right)$ at a mixed Eucalyptus obliqua forest stand, Wombat State Forest, Victoria (AUWOM) and at a mixed E. obliqua and E. regnans forest stand, Warra LTER, Tasmania, Australia (AU-WRR). Standardised coefficients $\beta$ are in parentheses. SD refers to standard deviation of parameter; level of significance ${ }^{*} p \geq 0.001$ ). Predictors: $T_{\mathrm{S}}$ (soil temperature), AFP (air-filled porosity) and soil VWC (volumetric water content). Presented constants are model intercepts and parameters represent the slopes for the predictor variables.

\begin{tabular}{|c|c|c|c|c|c|c|}
\hline Site & Dependent variable & Constant & $\operatorname{VWC}(\mathrm{SD}=0.051)$ & $T_{\mathrm{S}}(\mathrm{SD}=1.98)$ & $\operatorname{AFP}(\mathrm{SD}=0.488)$ & Adj. $R^{2}$ \\
\hline \multirow[t]{5}{*}{ AU-WRR } & $F_{\mathrm{CH}_{4}}(\mathrm{SD}=10.899)$ & $-92.307^{*}$ & $195.378^{*}(0.925)$ & - & - & $0.855^{*}$ \\
\hline & $F_{\mathrm{CH}_{4}}(\mathrm{SD}=10.899)$ & $-19.543^{*}$ & - & $-2.215^{*}(-0.399)$ & - & $0.158^{*}$ \\
\hline & $F_{\mathrm{CH}_{4}}(\mathrm{SD}=10.899)$ & $-88.835^{*}$ & $191.664 *(0.907)$ & $-0.254^{*}(-0.046)$ & - & $0.857^{*}$ \\
\hline & $F_{\mathrm{CH}_{4}}(\mathrm{SD}=10.899$ & $53.640^{*}$ & - & - & $-195.378^{*}(0.925)$ & $0.855^{*}$ \\
\hline & & Constant & $\operatorname{VWC}(\mathrm{SD}=0.055)$ & $T_{\mathrm{S}}(\mathrm{SD}=3.42)$ & $\operatorname{AFP}(S D=0.402)$ & Adj. $R^{2}$ \\
\hline \multirow[t]{4}{*}{ AU-WOM } & $F_{\mathrm{CH}_{4}}(\mathrm{SD}=11.296)$ & $-75.068^{*}$ & $195.768^{*}(0.957)$ & - & - & $0.915^{*}$ \\
\hline & $F_{\mathrm{CH}_{4}}(\mathrm{SD}=12.720)$ & $-6.320^{*}$ & - & $-1.701^{*}(-0.458)$ & - & $0.209^{*}$ \\
\hline & $F_{\mathrm{CH}_{4}}(\mathrm{SD}=10.607)$ & $-78.336^{*}$ & $201.671^{*}(0.982)$ & $0.147^{*}(0.047)$ & - & $0.900^{*}$ \\
\hline & $F_{\mathrm{CH}_{4}}(\mathrm{SD}=11.296)$ & $53.943^{*}$ & - & - & $-195.768^{*}(0.957)$ & $0.915^{*}$ \\
\hline
\end{tabular}

by 100. Furthermore, soil temperature and soil moisture data were averaged accordingly for each chamber cycle to allow regression analysis. In a second step, to enable correlation analysis with daily rainfall and sporadic soil inorganic nitrogen measurements we calculated daily site averages of the measured fluxes and environmental parameters, with the exception of rainfall where we calculated daily sums, for days where at least $80 \%$ of chamber cycles were available. In addition, we calculated the coefficient of variation per day $\left(\mathrm{CV} \%_{\text {day }}\right)$ for the $\mathrm{CH}_{4}$ flux data. As outlined above, we excluded fluxes where the coefficient of determination of the regression of chamber concentration vs. time was less than 0.9 , which lead to the exclusion of approximately $10 \%$ of measured chamber fluxes. However, longer gaps in flux data, as shown in Figs. 1a and 2a, are either a result of power failures or the need to switch off the power generators on days of extreme fire danger. This led to data gaps in around $30 \%$ of the individual datasets.

All statistical analyses were performed with SPSS 20 (IBM, USA). Linear regression procedures and multiple linear regression procedures were used to investigate temporal relationships between measured soil environmental parameters and soil $\mathrm{CH}_{4}$. We initially ran stepwise linear regression procedure as an exploratory tool to identify significant predictors and predictor combinations and retested these afterwards in simple or multiple linear regression models. We transformed data when necessary to reduce heteroscedasticity for linear regression analysis. We used a restricted maximum likelihood framework (REML; automatic linear modelling in SPSS) to arrive at the Akaike information criterion for three selected models that predict soil $\mathrm{CH}_{4}$ uptake (one model containing only soil temperature, one model containing only a measure of soil moisture (we choose air-filled porosity, AFP) and one model containing soil temperature and AFP as a predictors of soil $\mathrm{CH}_{4}$ flux.

\subsection{Annual site $\mathrm{CH}_{4}$ flux budgets}

To calculate annual site $\mathrm{CH}_{4}$ flux budgets for both sites we first selected a 12-month period with the greatest data coverage for daily average flux for both sites (1 January 20111 January 2012) and filled existing flux data gaps as follows. For small data gaps of single days where no environmental sensor or flux data were available, we calculated values based on linear interpolation between the $\mathrm{CH}_{4}$ flux of the day before the gap and the day after the gap. For data gaps longer than 1 day, we used the linear regression model between soil VWC soil moisture and daily soil $\mathrm{CH}_{4}$ flux for each site (Table 1) to estimate the missing $\mathrm{CH}_{4}$ flux data.

\section{Results}

\section{1 $\mathrm{CH}_{4}$ flux in relation to soil environmental variables}

At the AU-WRR site, soil $\mathrm{CH}_{4}$ flux was always negative indicating $\mathrm{CH}_{4}$ uptake all year round (Fig. 2). The measurement cycle means ranged between $-2 \mu \mathrm{CH}_{4} \mathrm{~m}^{-2} \mathrm{~h}^{-1}$ (spring 2010) to $-58.4 \mu \mathrm{g} \mathrm{CH}_{4} \mathrm{~m}^{-2} \mathrm{~h}^{-1}$ (autumn 2011) with an arithmetic mean of $-41.2 \pm 11.0 \mathrm{SD}_{\mu \mathrm{g} \mathrm{CH}} \mathrm{m}^{-2} \mathrm{~h}^{-1}$. In general, months with higher average soil moisture and higher total rainfall displayed lower $\mathrm{CH}_{4}$ uptake when compared to months with lower average soil moisture and lower total rainfall (Fig. 2). The coefficient of variance $(\mathrm{CV})$ for the average $\mathrm{CH}_{4}$ flux based on 10 chambers in one measurement cycle ranged between 1.8 and $98.0 \%$ with an average of $17.9 \pm 11 \%$ (SD) and was higher in periods of rapid changes in soil moisture levels reflecting changes in precipitation (Fig. 2)

At the AU-WOM site soil $\mathrm{CH}_{4}$ flux was always negative, indicating $\mathrm{CH}_{4}$ uptake all year round (Fig. 3). The measurement cycle means ranged between $-1.3 \mu \mathrm{g} \mathrm{CH}_{4} \mathrm{~m}^{-2} \mathrm{~h}^{-1}$ 


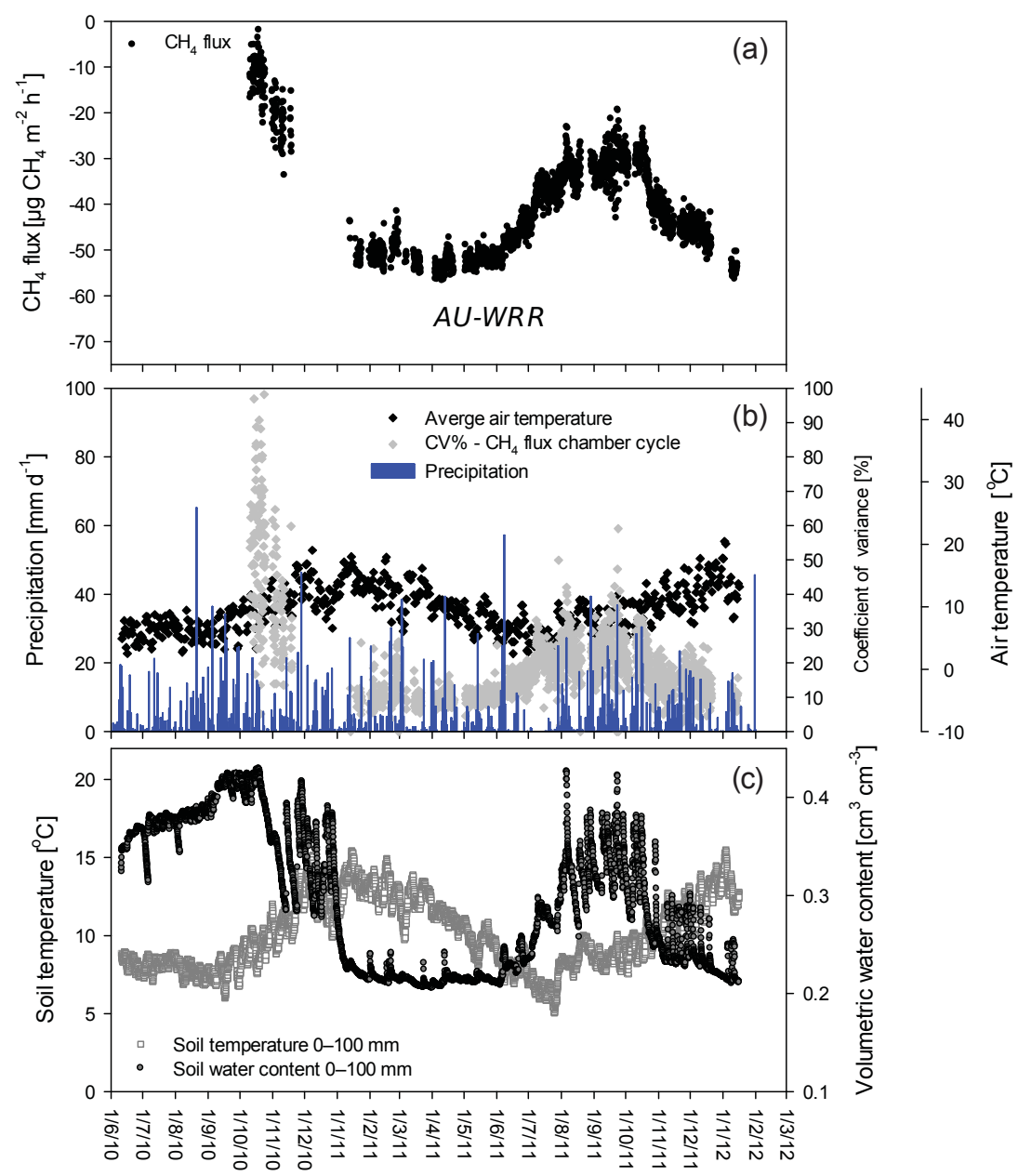

Figure 2. Soil-based flux of $\mathrm{CH}_{4}$ at a mixed Eucalyptus obliqua and E. regnans forest stand. Warra LTER, Tasmania, Australia (AU-WRR). Panel (a) shows $\mathrm{CH}_{4}$ flux cycle means of 10 chambers measured within a $4 \mathrm{~h}$ time period. Panel (b) shows site air temperature averaged over the chamber cycle period (black diamonds), daily rainfall sums (blue bars) and coefficient of variance of the $\mathrm{CH}_{4}$ flux cycle mean shown in (a) (grey diamonds). Panel (c) shows soil temperature in the top 0-10 cm averaged over each chamber cycle (grey squares) and corresponding soil volumetric water content (black/grey circles) at the site.

(recorded during a period of heavy rainfall in summer 2011) to $-62.5 \mu \mathrm{g} \mathrm{CH}_{4} \mathrm{~m}^{-2} \mathrm{~h}^{-1}$ (summer 2010) with an arithmetic mean of $-25.5 \pm 12.7 \mathrm{SD} \mu \mathrm{g} \mathrm{CH}_{4} \mathrm{~m}^{-2} \mathrm{~h}^{-1}$. Similar to the AU-WRR site, months with higher average soil moisture and higher total rainfall displayed lower $\mathrm{CH}_{4}$ uptake when compared to months with lower average soil moisture and lower total rainfall (Fig. 3). The $\mathrm{CV}$ for the average $\mathrm{CH}_{4}$ flux based on six chambers in one measurement cycle ranged between 6.7 and $143.0 \%$ with an average of $29.3 \pm 9.7 \%$ (SD) and was again higher in times of rapid soil moisture changes in response to changes in precipitation patterns (Fig. 3).

For AU-WRR the linear regression analysis showed that VWC accounted for approximately $85 \%$ of variability in soil $\mathrm{CH}_{4}$ uptake across all seasons (Fig. 4a, Table 1) with soil $\mathrm{CH}_{4}$ uptake decreasing when soil VWC increased or soil $\mathrm{CH}_{4}$ uptake increasing when AFP increased (Fig. 4b, Table 1$)$. Soil temperature $(0-5 \mathrm{~cm})$ alone was weakly related to $\mathrm{CH}_{4}$ uptake with higher $\mathrm{CH}_{4}$ uptake rates associated with higher soil temperatures. However, soil temperature alone was only able to account for approximately $16 \%$ of seasonal variability in $\mathrm{CH}_{4}$ uptake (Fig. 4c, Table 1). In addition, after taking the effect of VWC into account, soil temperature only explained around $1.5 \%$ of the remaining variability in $\mathrm{CH}_{4}$ uptake at AU-WRR (data not shown). A regression model containing VWC and soil temperature as input variables had only a marginally higher coefficient of determination when compared to the model only containing VWC (Table 1). Airfilled porosity or VWC showed some weak dependency of soil temperature at the site $\left(R^{2}=0.14, p<0.001\right)$.

For AU-WOM the linear regression analysis showed that VWC could account for around $91 \%$ of variability in soil $\mathrm{CH}_{4}$ uptake across all seasons (Fig. 4a, Table 1) with soil $\mathrm{CH}_{4}$ uptake decreasing when soil VWC increased, the opposite trend was observed for AFP (Fig. 4b, Table 1). Soil tem- 


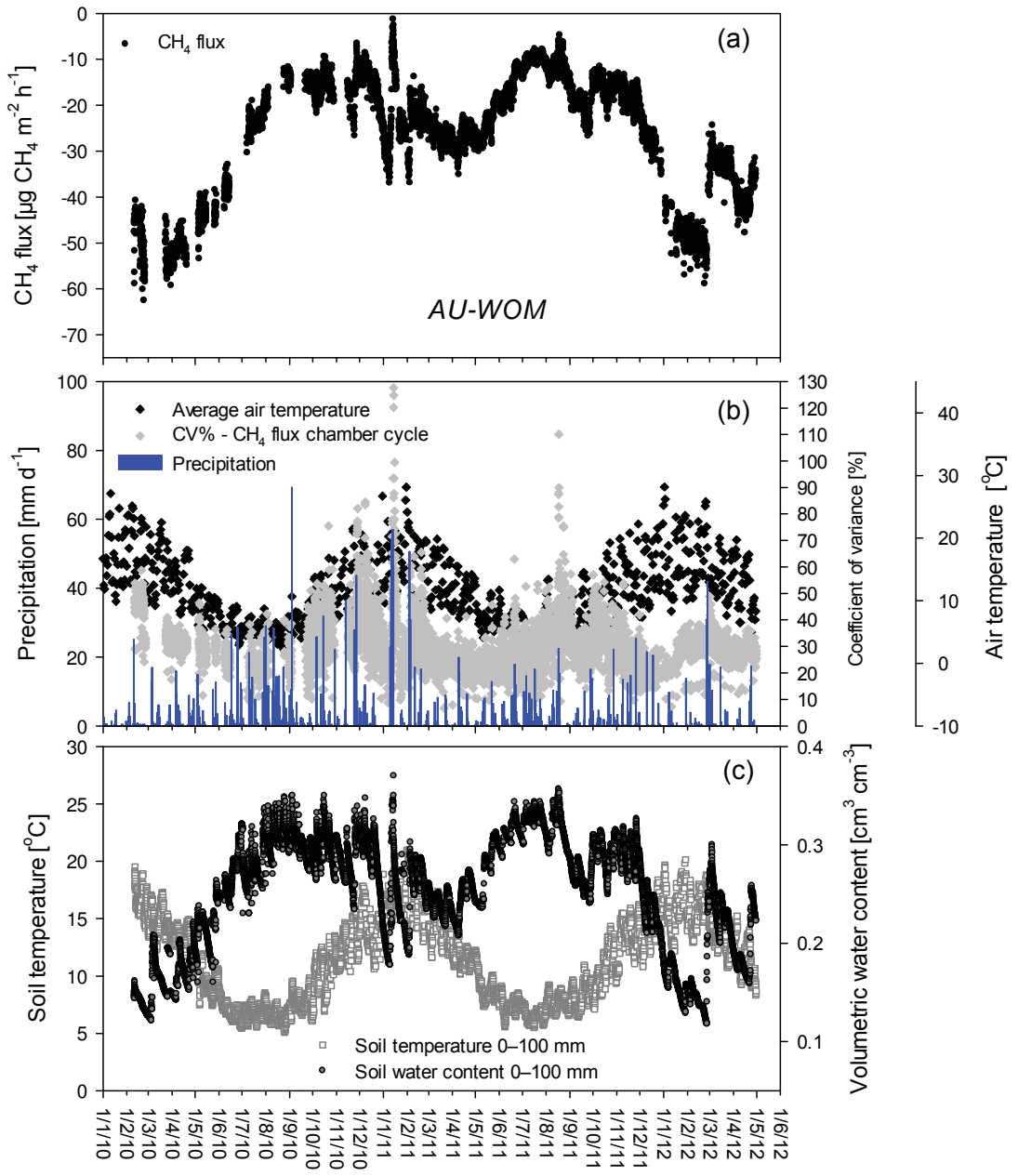

Figure 3. Soil-based flux of $\mathrm{CH}_{4}$ at a mixed Eucalyptus obliqua forest stand, Wombat State Forest, Victoria, Australia (AU-WOM). Panel (a) shows $\mathrm{CH}_{4}$ flux cycle means of six chambers measured within a $2 \mathrm{~h}$ time period. Panel (b) shows site air temperature averaged over the chamber cycle period (black diamonds), daily rainfall sums (blue bars) and coefficient of variance of the $\mathrm{CH}_{4}$ flux cycle mean shown in (a) (grey diamonds). Panel (c) shows soil temperature in the top 0-10 cm averaged over each chamber cycle (grey squares) and corresponding soil volumetric water content (black/grey circles) at the site.

Table 2. Parameters and coefficients of determination (Adj. $R^{2}$ ) of selected linear models in combination with results of a restricted maximum likelihood analysis (REML) explaining seasonal variability in mean chamber cycle methane flux $\left(F_{\mathrm{CH}_{4}}\right)$ at a mixed Eucalyptus obliqua forest stand, Wombat State Forest, Victoria (AU-WOM) and at a mixed E. obliqua and E. regnans forest stand, Warra LTER, Tasmania, Australia (AU-WRR). Predictors: $T_{\mathrm{S}}$ (soil temperature) and AFP (air-filled porosity). REML results: Akaike information criterion (AIC); Estimate of importance for models containing both predictors are in parentheses.

\begin{tabular}{|c|c|c|c|c|c|c|}
\hline Site & Dependent variable & Constant (intercept) & AFP (slope) & $T_{\mathrm{S}}$ (slope) & AIC & Adj. $R^{2}$ \\
\hline \multirow[t]{3}{*}{ AU-WRR } & $F_{\mathrm{CH}_{4}}$ & 53.640 & -195.378 & - & 5666 & 0.855 \\
\hline & $F_{\mathrm{CH}_{4}}$ & -19.543 & - & -2.215 & 9657 & 0.158 \\
\hline & $F_{\mathrm{CH}_{4}}$ & 55.587 & $-193.284(0.997)$ & $-0.254(0.003)$ & 5629 & 0.857 \\
\hline \multirow[t]{3}{*}{ AU-WOM } & $F_{\mathrm{CH}_{4}}$ & 53.943 & -195.768 & - & 7648 & 0.915 \\
\hline & $F_{\mathrm{CH}_{4}}$ & -6.320 & - & -1.701 & 13088 & 0.209 \\
\hline & $F_{\mathrm{CH}_{4}}$ & 54.766 & $-201.671(0.998)$ & $0.147(0.002)$ & 7617 & 0.900 \\
\hline
\end{tabular}



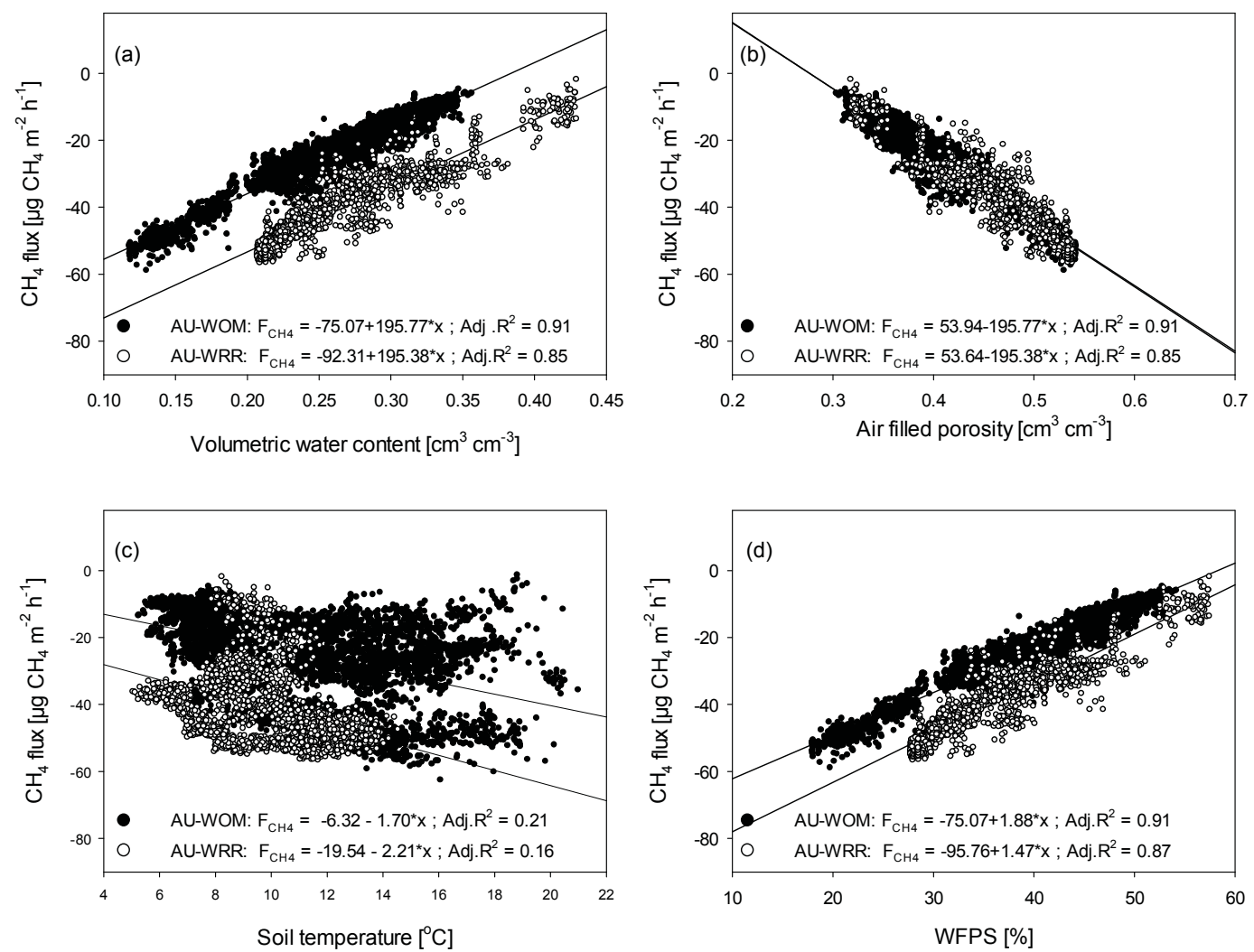

Figure 4. Relationships between soil volumetric water content and soil $\mathrm{CH}_{4}$ flux (a), soil air-filled porosity and soil $\mathrm{CH}_{4}$ flux (b), soil temperature and soil $\mathrm{CH}_{4}$ flux (c) and soil water-filled pore space (WFPS) and soil $\mathrm{CH}_{4}$ flux (d) for each chamber cycle at a mixed Eucalyptus obliqua forest stand, Wombat State Forest, Victoria (black circles, AU-WOM) and at a mixed E. obliqua and E. regnans forest stand, Warra LTER, Tasmania, Australia (white circles, AU-WRR). Lines symbolise significant linear regressions between the parameters (regression parameters are listed in Table 1).

perature $(0-5 \mathrm{~cm})$ alone was again weakly related to $\mathrm{CH}_{4}$ uptake with higher $\mathrm{CH}_{4}$ uptake rates associated with higher soil temperatures (Fig. 4c). At the AU-WOM site, only around $20 \%$ of seasonal variability in $\mathrm{CH}_{4}$ uptake (Table 1 ) was explained by soil temperature. In addition, similar to the results at AU-WRR, after taking the effect of VWC into account, soil temperature only explained around $5 \%$ of the remaining variability in $\mathrm{CH}_{4}$ uptake at AU-WOM (data not shown). Furthermore, a regression model containing VWC and soil temperature had a marginally lower coefficient of determination (Table 1) when compared to the model only containing VWC (Table 1). Air-filled porosity or VWC showed some weak dependency of soil temperature at the site $\left(R^{2}=0.38\right.$, $p<0.001$ ).

The AIC results of the REML analysis confirm the results of the linear regression approach (Table 2) showing that soil moisture (in this case expressed as AFP) is the strongest predictor of soil $\mathrm{CH}_{4}$ flux in both forest systems. The analysis shows that the models including soil moisture and soil temperature perform marginally better based on AIC compared to models including only soil moisture to predict soil $\mathrm{CH}_{4}$ flux. However, the importance rating of the predictors (soil moisture and soil temperature) clearly indicates that in both forest systems soil moisture dominates as it accounts for more than $99 \%$ of the proportion of variance explained by the model compared to $<0.01 \%$ proportion of the variance explained by soil temperature.

\subsection{Mean daily and annual $\mathrm{CH}_{4}$ flux in relation to environmental variables}

\subsubsection{Site AU-WRR}

Daily site averages ranged between -0.12 and $-1.35 \mathrm{mg} \mathrm{CH}_{4} \mathrm{~m}^{-2} \mathrm{~d}^{-1}$ with an arithmetic mean of $-0.98 \pm 0.27$ (SD) $\mathrm{mg} \mathrm{CH}_{4} \mathrm{~m}^{-2} \mathrm{~d}^{-1}$. The coefficient of determination for the regression analysis changed slightly when the regression analysis was calculated on daily means and VWC was able to account for up to $89 \%$ in the observed variability in $\mathrm{CH}_{4}$ flux (Table 3). The $\mathrm{CV}$ for the daily average site $\mathrm{CH}_{4}$ flux ranged between 0.15 and $20.6 \%$ with an average of $3.5 \pm 3.33 \%$ (SD) and was higher in periods of rapid changes in soil moisture levels. We calculated soil $\mathrm{CH}_{4}$ flux averages for 3 days around the dates when soil 
Table 3. Parameters and coefficients of determination (Adj. $R^{2}$ ) of linear regression models explaining seasonal variability in mean daily methane flux $\left(F_{\mathrm{CH}_{4}}\right)$ at a mixed Eucalyptus obliqua forest stand, Wombat State Forest, Victoria (AU-WOM) and at a mixed E. obliqua and E. regnans forest stand, Warra LTER, Tasmania, Australia (AU-WRR). Standardised coefficients $\beta$ are in parentheses; SD refers to standard deviation of parameter; level of significance $\left(^{*} \leq 0.001\right)$. Predictors: $T_{\mathrm{S}}$ (soil temperature), AFP (air-filled porosity) and soil VWC (volumetric water content). Presented constants are model intercepts and parameters represent the slopes for the predictor variables.

\begin{tabular}{|c|c|c|c|c|c|c|}
\hline Site & Dependent variable & Constant & $\operatorname{VWC}(\mathrm{SD}=0.058)$ & $T_{\mathrm{S}}(\mathrm{SD}=2.02)$ & $\operatorname{AFP}(\mathrm{SD}=0.058)$ & Adj. $R^{2}$ \\
\hline \multirow[t]{5}{*}{ AU-WRR } & $F_{\mathrm{CH}_{4}}(\mathrm{SD}=0.273)$ & $-2.165^{*}$ & $4.433^{*}(0.947)$ & - & - & $0.896^{*}$ \\
\hline & $F_{\mathrm{CH}_{4}}(\mathrm{SD}=0.273)$ & $-0.459^{*}$ & - & $-0.052^{*}(-0.388)$ & - & $0.148^{*}$ \\
\hline & $F_{\mathrm{CH}_{4}}(\mathrm{SD}=0.273)$ & $-2.167^{*}$ & $4.435^{*}(0.947)$ & $0.0001(0.001)$ & & $0.895^{*}$ \\
\hline & $F_{\mathrm{CH}_{4}}(\mathrm{SD}=0.273)$ & $1.164^{*}$ & - & - & $4.433^{*}(-0.947)$ & $0.896^{*}$ \\
\hline & & Constant & $\operatorname{VWC}(\mathrm{SD}=0.055)$ & $T_{\mathrm{S}}(\mathrm{SD}=3.55)$ & $\mathrm{AFP}(\mathrm{SD}=0.055)$ & Adj. $R^{2}$ \\
\hline \multirow[t]{4}{*}{ AU-WOM } & $F_{\mathrm{CH}_{4}}(\mathrm{SD}=0.275)$ & $-1.819^{*}$ & $4.771^{*}(0.962)$ & - & & $0.924^{*}$ \\
\hline & $F_{\mathrm{CH}_{4}}(\mathrm{SD}=0.302)$ & $-0.161^{*}$ & - & $-0.038^{*}(-0.452)$ & & $0.203^{*}$ \\
\hline & $F_{\mathrm{CH}_{4}}(\mathrm{SD}=0.275)$ & $-1.915^{*}$ & $4.956^{*}(0.999)$ & $0.004^{*}(0.053)$ & & $0.926^{*}$ \\
\hline & $F_{\mathrm{CH}_{4}}(\mathrm{SD}=0.275)$ & $1.152^{*}$ & - & - & $-4.771^{*}(-0.962)$ & $0.924^{*}$ \\
\hline
\end{tabular}
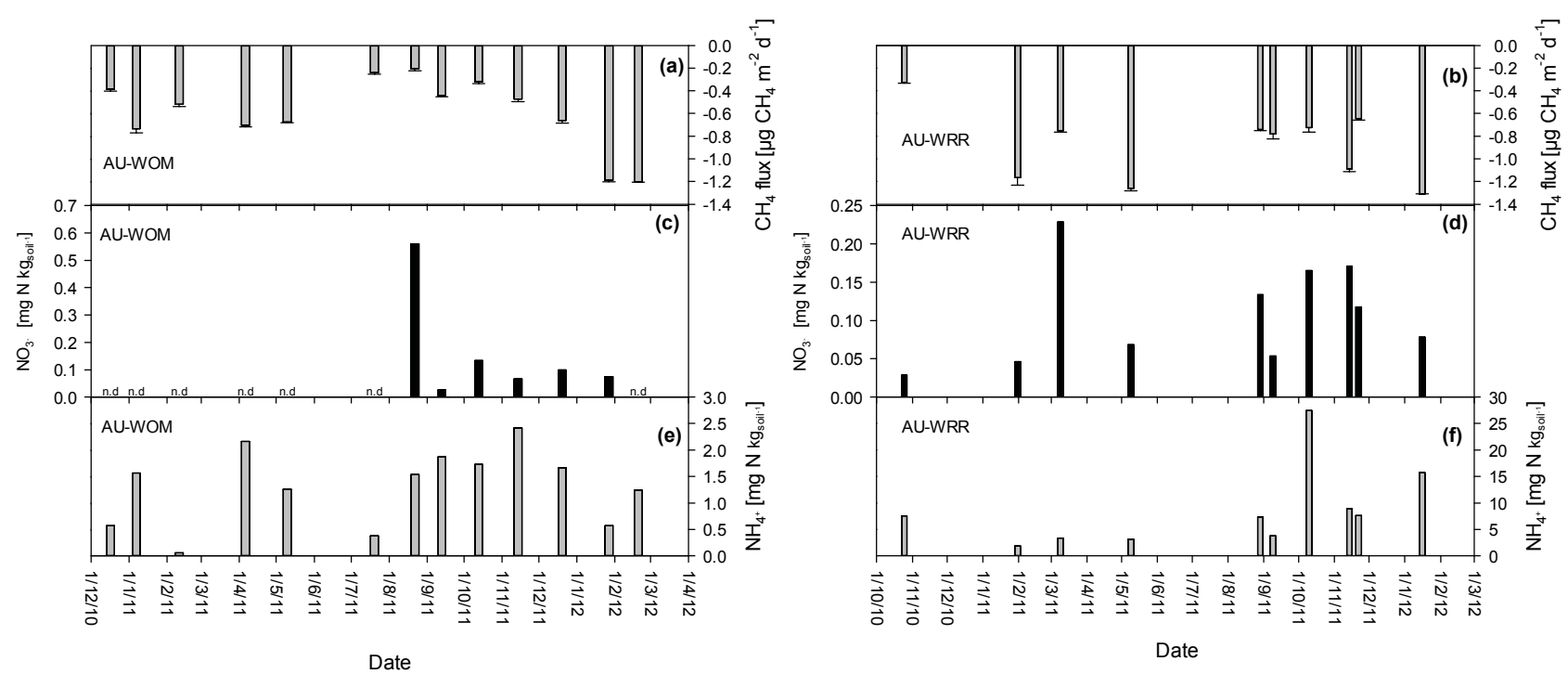

Figure 5. Dynamics in soil $\mathrm{CH}_{4}$ flux (a, b) soil nitrate levels (c, d) and soil ammonium levels (e, f) at a mixed Eucalyptus obliqua forest stand, Wombat State Forest, Victoria (AU-WOM) and a mixed E. obliqua and E. regnans forest stand, Warra LTER, Tasmania (AU-WRR), Australia; n.d means not detectable. Results of the linear regression analysis between $\mathrm{CH}_{4}$ and $\mathrm{NH}_{4}^{+}$or $\mathrm{NO}_{3}^{-}$for both sites are not presented. They were AU-WOM: $\mathrm{NO}_{3}^{-} / \mathrm{CH}_{4}\left(\right.$ Adj. $\left.R^{2}=0.06, p=0.21\right) \mathrm{NH}_{4}^{+} / \mathrm{CH}_{4}\left(\right.$ Adj. $\left.R^{2}=-0.08, p=0.83\right)$; AU-WRR: $\mathrm{NO}_{3}^{-} / \mathrm{CH}_{4}(\mathrm{Adj}$. $\left.R^{2}=-0.11, p=0.80\right) \mathrm{NH}_{4}^{+} / \mathrm{CH}_{4}\left(\right.$ Adj. $\left.R^{2}=-0.11, p=0.84\right)$.

$\mathrm{NH}_{4}^{+}$and soil $\mathrm{NO}_{3}^{-}$samples were taken on-site to enable regression analysis; however, neither $\mathrm{NH}_{4}^{+}$nor $\mathrm{NO}_{3}^{-}$alone or together could explain any variability in soil $\mathrm{CH}_{4}$ flux at the site and all relationships were non-significant (Fig. 5b, d, f).

\subsubsection{Site AU-WOM}

Daily site averages ranged between -0.11 and $-1.36 \mathrm{mg} \mathrm{CH}_{4} \mathrm{~m}^{-2} \mathrm{~d}^{-1}$ with an arithmetic mean of $-0.62 \pm 0.30$ (SD) $\mathrm{mg} \mathrm{CH}_{4} \mathrm{~m}^{-2} \mathrm{~d}^{-1}$. The $\mathrm{CV}$ for the daily average site $\mathrm{CH}_{4}$ flux ranged between 0.11 and $47.6 \%$ with an average of $5.6 \pm 4.36 \%$ (SD) and was again higher in periods of rapid changes in soil moisture levels. As for the AU-WRR site the coefficient of determination for the regression analysis changed slightly when the regression analysis was calculated on daily means and VWC was able to account for up to $92 \%$ in the observed variability in $\mathrm{CH}_{4}$ flux (Table 3). Similar to the AU-WRR site, 3-day $\mathrm{CH}_{4}$ flux averages were not significantly correlated with soil $\mathrm{NH}_{4}^{+}$or $\mathrm{NO}_{3}^{-}$if entered alone or together as predictors to the linear regression model (Fig. 5a, c, e). 


\subsection{Annual site $\mathrm{CH}_{4}$ flux budgets}

The calculated annual $\mathrm{CH}_{4}$ budget for the year 2011 of the AU-WRR site was $-3.83 \mathrm{~kg} \mathrm{CH}_{4} \mathrm{ha}^{-1} \mathrm{yr}^{-1}$. The calculated annual $\mathrm{CH}_{4}$ budget for the year 2011 of the AU-WOM site was $-1.79 \mathrm{~kg} \mathrm{CH}_{4} \mathrm{ha}^{-1} \mathrm{yr}^{-1}$.

\section{Discussion}

One of the most novel results of our study is the strong linear relationship observed between soil moisture and $\mathrm{CH}_{4}$ uptake. To our knowledge the strength of this relationship is unique for temperate forest systems measured using continuous automated chamber systems over a long period. It is also striking that this strong linear relationship was similar in the two temperate eucalypt forests (dry and wet) regardless of the differences in forest structure, soil type, annual precipitation and geographical distance. It is possible that the two different measurement systems (GC at AU-WRR and FTIR at AUWOM) could produce different measures of $\mathrm{CH}_{4}$ flux if operated at the same site because of technological and methodological differences. If that were true, there would only be a remote chance that the two linear relationships between $\mathrm{CH}_{4}$ flux and AFP would overlap one another. As such, our finding that the relationships between $\mathrm{CH}_{4}$ flux and AFP do converge into one common regression line (as shown in Fig. 4) is worth noting and suggests similar accuracy between the two measurement systems and similar function in soil $\mathrm{CH}_{4}$ exchange processes at the two forest sites.

$\mathrm{CH}_{4}$ flux data collected in the long-term in temperate deciduous forest systems in Europe (Butterbach-Bahl and Papen, 2002) has shown that soil moisture can explain up to $58 \%$ of the seasonality in soil $\mathrm{CH}_{4}$ uptake. Similarly, Kiese et al. (2003) reported that soil moisture could explain up to $53 \%$ of the seasonality in $\mathrm{CH}_{4}$ exchange in a tropical rainforests in Queensland, Australia. Soil moisture influences soil gas diffusivity and is considered the most important factor controlling seasonality of $\mathrm{CH}_{4}$ uptake in soils worldwide (Dalal et al., 2008; Dalal and Allen, 2008; Smith et al., 2003, 2000; Ball et al., 1997) and the negative relationship between soil moisture and soil $\mathrm{CH}_{4}$ uptake reported in this study has been previously reported for other ecosystems (Hartmann et al., 2011; Stiehl-Braun et al., 2011; Castro et al., 1994; Price et al., 2003). This agrees with the theory that soil $\mathrm{CH}_{4}$ uptake is mainly limited by diffusion in most forest ecosystems (Price et al., 2004) when the sites of microbial $\mathrm{CH}_{4}$ oxidation are distributed through the surface soil (Stiehl-Braun et al., 2011) and the concentration gradient between soil and atmosphere, which drives the flux, is effectively constant (von Fischer and Hedin, 2007). However, previous field studies have never been able to demonstrate so conclusively the strength of the relationship ( $>90 \%$ variation explained) between AFP and soil $\mathrm{CH}_{4}$ uptake and for two separate forest systems. To our knowledge the only other study where similarly strong correlations between soil moisture and $\mathrm{CH}_{4}$ uptake have been reported was for grassland soils under summer rainfall exclusion (Hartmann et al., 2011).

It is important to note that WFPS has commonly been used to model, or compare, soil $\mathrm{CH}_{4}$ uptake in different ecosystems (Del Grosso et al., 2000). However, in our study this soil environmental variable was not as effective as AFP in explaining the observed $\mathrm{CH}_{4}$ flux patterns at the two temperate forest sites. At an individual site level, the relationship between WFPS and $\mathrm{CH}_{4}$ uptake had the same coefficient of determination as between AFP and $\mathrm{CH}_{4}$ uptake; however, the slope of the relationship differed between the two forest sites (Fig. 4d). This suggests that WFPS is not the most suitable soil moisture metric to relate soil gas diffusivity to soil $\mathrm{CH}_{4}$ flux when comparing sites or ecosystems. This is most likely due to the fact that WFPS is a proportional measure that relates VWC to the total soil porosity (Eq. 4); compared to AFP that is a direct expression of the air-filled pore volume in a given soil (Eq. 5).

This demonstrates that soil gas diffusivity is primarily related to the volumetric fractions of air (AFP), rather than the volumetric fraction of water in the soil since diffusion through air is much faster than through water (Farquharson and Baldock, 2008).

Our data also show a very weak influence by soil temperature on soil $\mathrm{CH}_{4}$ uptake. This temperature effect appears to be mainly driven by the correlation between soil moisture and soil temperature, which is typical for the climate of the investigated forest systems. After the effect of soil moisture was accounted for, soil temperature was only able to account for less than $5 \%$ of the remaining variability in soil $\mathrm{CH}_{4}$ flux at AU-WOM and less than $1.5 \%$ of the remaining variability in soil $\mathrm{CH}_{4}$ flux at AU-WRR. Furthermore, the daily temperature variation in soil $\mathrm{CH}_{4}$ uptake would have been masked in the analyses because all regression analyses were performed on either chamber cycle or daily uptake means. However, the overall weak but statistically significant temperature dependency of soil $\mathrm{CH}_{4}$ uptake is unlikely to greatly influence seasonal $\mathrm{CH}_{4}$ flux variability given that at both sites around $90 \%$ of seasonal variability in $\mathrm{CH}_{4}$ uptake can be explained by soil moisture alone and that soil moisture and temperature are weakly correlated in the investigated forest systems. This was more pronounced at the AU-WOM site because temporal soil moisture variability was greater and we had 2 years of data compared to 1 year of data at the AU-WRR site. However, a model that includes soil temperature and soil moisture together performed marginally better based on the AIC as compared to a model that only used soil moisture status in predicting soil $\mathrm{CH}_{4}$ flux at both of our sites, which is logical based on the fact that all soil microbial processes show a physiological temperature response; but it appears that for the MOB, temperature response is rather muted at our sites during our measurement time frame. Furthermore, our data also show that soil $\mathrm{CH}_{4}$ uptake still continued at a very low WFPS of $10 \%\left(\mathrm{VWC}=0.07 \mathrm{~g} \mathrm{~cm}^{-3}\right.$, 
$\mathrm{AFP}=0.59 \mathrm{~cm}^{3} \mathrm{~cm}^{-3}$ ) with $\mathrm{CH}_{4}$ uptake ranging between -62 to $-80 \mu \mathrm{g} \mathrm{CH}_{4} \mathrm{~m}^{-2} \mathrm{~h}^{-1}$ at this time. We can therefore hypothesise that MOB activity was not severely limited by moisture at the AU-WOM and the AU-WRR sites during the measurement period.

This study reports continuous measurement of soilatmosphere $\mathrm{CH}_{4}$ exchange in two temperate eucalypt forests in Australia measured at high-temporal resolution for $>12$ months. Mean daily $\mathrm{CH}_{4}$ flux values (AU-WRR $=-1.35$ to $-0.12 \mathrm{mg} \mathrm{CH}_{4} \mathrm{~m}^{-2} \mathrm{~d}^{-1}$; AU$\mathrm{WOM}=-1.36$ to $-0.11 \mathrm{mg} \mathrm{CH}_{4} \mathrm{~m}^{-2} \mathrm{~d}^{-1}$ ) were well within the reported range for other temperate forests in Europe ( -2.47 to $+0.26 \mathrm{mg} \mathrm{CH}_{4} \mathrm{~m}^{-2} \mathrm{~d}^{-1}$; Smith et al., 2000) or worldwide ( -10.68 to $0.02 \mathrm{mg} \mathrm{CH}_{4} \mathrm{~m}^{-2} \mathrm{~d}^{-1}$; Dalal et al., 2008; Dalal and Allen, 2008).

The estimated annual $\mathrm{CH}_{4}$ uptake of $-1.79 \mathrm{~kg} \mathrm{CH}_{4} \mathrm{ha}^{-1} \mathrm{yr}^{-1}$ for AU-WOM and $-3.83 \mathrm{~kg} \mathrm{CH}_{4} \mathrm{ha}^{-1} \mathrm{yr}^{-1}$ for AU-WRR are comparable to the range of -2.5 to $-3.7 \mathrm{~kg} \mathrm{CH}_{4} \mathrm{ha}^{-1} \mathrm{yr}^{-1}$ reported for temperate beech and spruce forest sites in Germany where $\mathrm{CH}_{4}$ fluxes were measured with a similar automated system over multiple years (Butterbach-Bahl and Papen, 2002). Globally, a range of -1.31 to $-10.5 \mathrm{~kg} \mathrm{CH}_{4} \mathrm{ha}^{-1} \mathrm{yr}^{-1}$ has been reported for temperate forest systems based on shortand long-term automated and manual chamber measurement campaigns (Dalal et al., 2008; Dalal and Allen, 2008). The annual $\mathrm{CH}_{4}$ uptake rate estimated for AU-WOM in our study was less than a third of the $-5.8 \mathrm{~kg} \mathrm{CH}_{4} \mathrm{ha}^{-1} \mathrm{yr}^{-1}$ estimated by Meyer et al. (1997) for soils in the same forest system. This earlier $\mathrm{CH}_{4}$ sink estimate was based on only five seasonal flux measurements but might also be attributed to the measurements being taken during three dry years (1993-1995) when average rainfall was $677 \mathrm{~mm} \mathrm{yr}^{-1}$ (Meyer et al., 1997). In comparison, the years when our study was undertaken (2010-2012), the average rainfall was $1063 \mathrm{~mm} \mathrm{yr}^{-1}$. This may partly explain the greater $\mathrm{CH}_{4}$ uptake estimate of Meyer et al. (1997) as the lower soil moisture levels may well lead to greater $\mathrm{CH}_{4}$ uptake rates.

\section{Conclusion}

Our field data suggest that the difference in magnitude of $\mathrm{CH}_{4}$ flux at both sites was based solely on differences in AFP due to site differences in soil bulk density, soil porosity as a near-identical relationship between AFP and soil $\mathrm{CH}_{4}$ uptake existed at both sites. This means that future research should investigate whether simple information about soil bulk density can be used to estimate $\mathrm{CH}_{4}$ uptake across different eucalypt forest ecosystems in Australia, or in other similar ecosystems globally. Our data further demonstrate that temporal variability in soil $\mathrm{CH}_{4}$ uptake was predominantly controlled by temporal variability in soil AFP that is linked to soil gas diffusivity. This means that seasonality in $\mathrm{CH}_{4}$ uptake can be predicted with very high accuracy where information about soil moisture dynamics is available or can be simulated with high certainty. However, since soil texture at both sites was relatively coarse and soils were both clay loams further studies need to establish if the AFP to $\mathrm{CH}_{4}$ relationship holds true across different soil texture classes. Our results highlight the importance of long-term field measurements in establishing relationships between soil environmental drivers and soil $\mathrm{CH}_{4}$ uptake and allowing the calibration of models used to calculate global $\mathrm{CH}_{4}$ sink distribution and magnitude.

\section{Data availability}

The dataset can be accessed here: doi: $10.4225 / 49 / 588574690 \mathrm{c} 0 \mathrm{ec}$ (Fest, 2017).

Acknowledgements. The study was supported by funding from the Terrestrial Ecosystem Research Network (TERN) Australian Supersite Network, the TERN OzFlux Network, the Australian Research Council (ARC, grants LE0882936 and DP120101735) and the Victorian Department of Environment, Land, Water and Planning Integrated Forest Ecosystem Research program. We would like to thank Julio Najera and student volunteers for assistance with site and instrument maintenance.

Edited by: G. Wohlfahrt

Reviewed by: three anonymous referees

\section{References}

Ashworth, J., Keyes, D., Kirk, R., and Lessard, R.: Standard procedure in the hydrometer method for particle size analysis, Commun. Soil. Sci. Plan., 32, 633-642, 2001.

Ball, B. C., Dobbie, K. E., Parker, J. P., and Smith, K. A.: The influence of gas transport and porosity on methane oxidation in soils, J. Geophys. Res.-Atmos., 102, 23301-23308, 1997.

Boeckx, P., van Cleemput, O., and Villaralvo, I.: Methane oxidation in soils with different textures and land use, Nutr. Cycl. Agroecosys., 49, 91-95, 1997.

Born, M., Dorr, H., and Levin, I.: Methane consumption in aerated soils of the temperate zone, Tellus B, 42, 2-8, doi:10.1034/j.1600-0889.1990.00002.x, 1990.

Butterbach-Bahl, K. and Papen, H.: Four years continuous record of $\mathrm{CH}_{4}$-exchange between the atmosphere and untreated and limed soil of a N-saturated spruce and beech forest ecosystem in Germany, Plant. Soil., 240, 77-90, 2002.

Butterbach-Bahl, K., Gasche, R., Breuer, L., and Papen, H.: Fluxes of $\mathrm{NO}$ and $\mathrm{N}_{2} \mathrm{O}$ from temperate forest soils: impact of forest type, $\mathrm{N}$ deposition and of liming on the $\mathrm{NO}$ and $\mathrm{N}_{2} \mathrm{O}$ emissions, Nutr. Cycl. Agroecosys., 48, 79-90, 1997.

Butterbach-Bahl, K., Gasche, R., Huber, C. H., Kreutzer, K., and Papen, $\mathrm{H}$.: Impact of $\mathrm{N}$-input by wet deposition on $\mathrm{N}$-trace gas fluxes and $\mathrm{CH}_{4}$-oxidation in spruce forest ecosystems of the temperate zone in Europe, Atmos. Envrion., 32, 559-564, 1998. 
Butterbach-Bahl, K., Rothe, A., and Papen, H.: Effect of tree distance on $\mathrm{N}_{2} \mathrm{O}$ and $\mathrm{CH}_{4}$-fluxes from soils in temperate forest ecosystems, Plant. Soil., 240, 91-103, 2002.

Castro, M. S., Melillo, J. M., Steudler, P. A., and Chapman, J. W.: Soil-moisture as a predictor of methane uptake by temperate forest soils, Can. J. Forest. Res., 24, 1805-1810, 1994.

Castro, M. S., Steudler, P. A., Melillo, J. M., Aber, J. D., and Bowden, R. D.: Factors Controlling Atmospheric Methane Consumption by Temperate Forest Soils, Global. Biogeochem. Cy., 9, 110, 1995.

Montreal Process Implementation Group for Australia and National Forest Inventory Steering Committee: Australia's State of the Forests Report 2013, Australian Government Department of Agricutlure ABARES, Canberra, 38, 2013.

Crill, P. M.: Seasonal patterns of methane uptake and carbon dioxide release by a temperate woodland soil, Global. Biogeochem. Сy., 5, 319-334, 1991.

Dalal, R. C. and Allen, D. E.: Greenhouse gas fluxes from natural ecosystems, Aust. J. Bot, 56, 369-407, doi:10.1071/bt07128, 2008.

Dalal, R. C., Allen, D. E., Livesley, S. J., and Richards, G.: Magnitude and biophysical regulators of methane emission and consumption in the Australian agricultural, forest, and submerged landscapes: a review, Plant. Soil., 309, 43-76, doi:10.1007/s11104-007-9446-7, 2008.

Del Grosso, S. J., Parton, W. J., Mosier, A. R., Ojima, D. S., Potter, C. S., Borken, W., Brumme, R., Butterbach-Bahl, K., Crill, P. M., Dobbie, K., and Smith, K. A.: General $\mathrm{CH}_{4}$ oxidation model and comparisons of $\mathrm{CH}_{4}$ oxidation in natural and managed systems, Global. Biogeochem. Cy., 14, 999-1019, 2000.

Dick, J., Skiba, U., Munro, R., and Deans, D.: Effect of N-fixing and non $\mathrm{N}$-fixing trees and crops on $\mathrm{NO}$ and $\mathrm{N}_{2} \mathrm{O}$ emissions from Senegalese soils, J. Biogeogr., 33, 416-423, 2006.

Dunlop, M. and Brown, P. R.: Implications of climate change for Australia's National Reserve System: A preliminary assessment. Report to the Department of Climate Change, February 2008, Department of Climate Change, Canberra, Australia, Canberra, 196, 2008.

Dutaur, L. and Verchot, L. V.: A global inventory of the soil $\mathrm{CH}_{4}$ sink, Global. Biogeochem. Cy., 21, GB4013, doi:10.1029/2006gb002734, 2007.

Farquharson, R. and Baldock, J.: Concepts in modelling $\mathrm{N}_{2} \mathrm{O}$ emissions from land use, Plant. Soil., 309, 147-167, 2008.

Fest, B.: The impact of fire disturbance and simulated climate change conditions on soil methane exchange in euclypt forests of south-eastern Australia, PhD, School of Ecosystem and Forest Sciences, The University of Melbourne, Melbourne, 185 pp., 2013.

Fest, B.: Soil-atmosphere methane exchange data for AU-WOM and AU-WRR with soil environmental variables, University of Melbourne, doi:10.4225/49/588574690c0ec, 2017.

Fest, B. J., Livesley, S. J., Drösler, M., van Gorsel, E., and Arndt, S. K.: Soil-atmosphere greenhouse gas exchange in a cool, temperate Eucalyptus delegatensis forest in south-eastern Australia, Agr. Forest. Meteorol., 149, 393-406, 2009.

Fest, B., Wardlaw, T., Livesley, S. J., Duff, T. J., and Arndt, S. K.: Changes in soil moisture drive soil methane uptake along a fire regeneration chronosequence in a eucalypt forest landscape,
Glob. Change. Biol., 21, 4250-4264, doi:10.1111/gcb.13003, 2015a.

Fest, B. J., Livesley, S. J., von Fischer, J. C., and Arndt, S. K.: Repeated fuel reduction burns have little long-term impact on soil greenhouse gas exchange in a dry sclerophyll eucalypt forest, Agr. Forest. Meteorol., 201, 17-25, doi:10.1016/j.agrformet.2014.11.006, 2015b.

Griffith, D. W. T., Deutscher, N. M., Caldow, C., Kettlewell, G., Riggenbach, M., and Hammer, S.: A Fourier transform infrared trace gas and isotope analyser for atmospheric applications, Atmos. Meas. Tech., 5, 2481-2498, doi:10.5194/amt-5-2481-2012, 2012.

Hammer, S., Griffith, D. W. T., Konrad, G., Vardag, S., Caldow, C., and Levin, I.: Assessment of a multi-species in situ FTIR for precise atmospheric greenhouse gas observations, Atmos. Meas. Tech., 6, 1153-1170, doi:10.5194/amt-6-1153-2013, 2013.

Hartmann, A. A., Buchmann, N., and Niklaus, P. A.: A study of soil methane sink regulation in two grasslands exposed to drought and N fertilization, Plant. Soil., 342, 265-275, doi:10.1007/s11104-010-0690-x, 2011.

IPCC: The Scientific Basis. Contribution of Working Group I to the Fifth Assessment Report of the intergovernmental Panel on Climate Change Cambridge University Press, Cambridge, United Kingdom and New York, NY, USA, 1535, 2013.

Kaleita, A. L., Heitman, J. L., and Logsdon, S. D.: Field Calibration of the Theta Probe for Des Moines Lobe Soils, Appl. Eng. Agric., 21, 865-870, 2005.

Khalil, M. I. and Baggs, E. M.: $\mathrm{CH}_{4}$ oxidation and $\mathrm{N}_{2} \mathrm{O}$ emissions at varied soil water-filled pore spaces and headspace $\mathrm{CH}_{4}$ concentrations, Soil. Biol. Biochem., 37, 1785-1794, 2005.

Kiese, R., Hewett, B., Graham, A., and Butterbach-Bahl, K.: Seasonal variability of $\mathrm{N}_{2} \mathrm{O}$ emissions and $\mathrm{CH}_{4}$ uptake by tropical rainforest soils of Queensland, Australia, Global. Biogeochem. Cy., 17, 1043, doi:10.1029/2002gb002014, 2003.

Livesley, S. J., Kiese, R., Miehle, P., Weston, C. J., ButterbachBahl, K., and Arndt, S. K.: Soil-atmosphere exchange of greenhouse gases in a Eucalyptus marginata woodland, a clovergrass pasture, and Pinus radiata and Eucalyptus globulus plantations, Glob. Change Biol., 15, 425-440, doi:10.1111/j.13652486.2008.01759.x, 2009.

Livesley, S. J., Grover, S., Hutley, L. B., Jamali, H., ButterbachBahl, K., Fest, B., Beringer, J., and Arndt, S. K.: Seasonal variation and fire effects on $\mathrm{CH}_{4}, \mathrm{~N}_{2} \mathrm{O}$ and $\mathrm{CO}_{2}$ exchange in savanna soils of northern Australia, Agr. Forest. Meteorol., 151, 1440 1452, 2011.

Loveday, J. and Commonwealth Bureau of Soils: Methods for analysis of irrigated soils, Commonwealth Agricultural Bureaux, Farnham Royal, Buckinghamshire, 208 pp., 1973.

McIntosh, P. D.: Soil characterisation at the Warra Flux Tower supersite, Version 2, with supplementary data, Forest Practices Authority Contract Report, prepared for Forestry Tasmania, 16 pp., 2012.

Meyer, C. P., Galbally, I. E., Wang, Y., Weeks, I. A., Jamie, I., and Griffith, D. W. T.: Two automatic chamber techniques for measuring soil-atmosphere exchanges of trace gases and results of their use in the OASIS filed experiment, CSIRO Australia, Aspendale, 33, 2001.

Meyer, C. P., Galbally, I. E., Wang, Y.-P., Weeks, I. A., Tolhurst, K. G., and Tomkins, I. B.: The enhanced emission of greenhouse 
gases from soil following prescribed burning in a southern eucalyptus forest. Final report to the National Greenhouse Gas Inventory Committee, CSIRO, Division of Atmospheric Research, Aspendale, Victoria, 1-66, 1997.

Niklaus, P. A., Wardle, D. A., and Tate, K. R.: Effects of Plant Species Diversity and Composition on Nitrogen Cycling and the Trace Gas Balance of Soils, Plant. Soil., 282, 83-98, doi:10.1007/s11104-005-5230-8, 2006.

Ojima, D. S., Valentine, D. W., Mosier, A. R., Parton, W. J., and Schimel, D. S.: Effect of land-use change on methane oxidation in temperate forest and grassland soils, Chemosphere, 26, 675685, 1993.

Papen, H. and Butterbach-Bahl, K.: A 3-year continuous record of nitrogen trace gas fluxes from untreated and limed soil of a $\mathrm{N}$ saturated spruce and beech forest ecosystem in Germany - 1 . $\mathrm{N}_{2} \mathrm{O}$ emissions, J. Geophys. Res.-Atmos., 104, 18487-18503, 1999.

Price, S. J., Sherlock, R. R., Kelliher, F. M., McSeveny, T. M., Tate, K. R., and Condron, L. M.: Pristine New Zealand forest soil is a strong methane sink, Glob. Change. Biol., 10, 16-26, 2003.

Price, S. J., Kelliher, F. M., Sherlock, R. R., Tate, K. R., and Condron, L. M.: Environmental and chemical factors regulating methane oxidation in a New Zealand forest soil, Aust. J. Soil Res., 42, 767-776, doi:10.1071/SR04026, 2004.

Robinson, N., Rees, D., Reynard, K., MacEwan, R., Dahlhaus, P., Imhof, M., Boyle, G., and Baxter, N.: A land resource assessment of the Corangamite region, Primary Industries Research Victoria, Bendigo, Victoria, 121, 2003.
Sitaula, B. K., Bakken, L. R., and Abrahamsen, G.: $\mathrm{CH}_{4}$ uptake by temperate forest soi-effect of $\mathrm{N}$ input and soil acidification, Soil. Biol. Biochem., 27, 871-880, 1995.

Smith, K. A., Dobbie, K. E., Ball, B. C., Bakken, L. R., Sitaula, B. K., Hansen, S., Brumme, R., Borken, W., Christensen, S., Prieme, A., Fowler, D., Macdonald, J. A., Skiba, U., Klemedtsson, L., Kasimir-Klemedtsson, A., Degorska, A., and Orlanski, P.: Oxidation of atmospheric methane in Northern European soils, comparison with other ecosystems, and uncertainties in the global terrestrial sink, Glob. Change. Biol., 6, 791-803, 2000.

Smith, K. A., Ball, T., Conen, F., Dobbie, K. E., Massheder, J., and Rey, A.: Exchange of greenhouse gases between soil and atmosphere: interactions of soil physical factors and biological processes, Eur. J. Soil. Sci., 54, 779-791, doi:10.1046/j.13510754.2003.0567.x, 2003.

Stiehl-Braun, P. A., Hartmann, A. A., Kandeler, E., Buchmann, N., and Niklaus, P. A.: Interactive effects of drought and $\mathrm{N}$ fertilization on the spatial distribution of methane assimilation in grassland soils, Glob. Change. Biol., 17, 2629-2639, doi:10.1111/j.1365-2486.2011.02410.x, 2011.

von Fischer, J. C. and Hedin, L. O.: Controls on soil methane fluxes: Tests of biophysical mechanisms using stable isotope tracers, Global. Biogeochem. Cy., 21, GB2007, doi:10.1029/2006GB002687, 2007. 